\title{
Comparative Phylogeography of the Coral Triangle and Implications for Marine Management
}

\author{
Kent E. Carpenter, ${ }^{1}$ Paul H. Barber, ${ }^{2}$ Eric D. Crandall, ${ }^{3}$ \\ Ma. Carmen A. Ablan-Lagman, ${ }^{4}$ Ambariyanto, ${ }^{5}$ Gusti Ngurah Mahardika, ${ }^{6}$ \\ B. Mabel Manjaji-Matsumoto, ${ }^{7}$ Marie Antonette Juinio-Meñez, ${ }^{8}$ \\ Mudjekeewis D. Santos, ${ }^{9}$ Craig J. Starger, ${ }^{2}$ and Abdul Hamid A. Toha ${ }^{10}$ \\ ${ }^{1}$ Biological Sciences and International Union for Conservation of Nature/Conservation International Global \\ Marine Species Assessment, Old Dominion University, Norfolk, VA 23529, USA \\ ${ }^{2}$ Department of Ecology and Evolutionary Biology, University of California Los Angeles, 621 Charles E. Young Dr. South, \\ Los Angeles, CA 90095, USA \\ ${ }^{3}$ Biological Sciences, Old Dominion University, Norfolk, VA 23529, USA \\ ${ }^{4}$ Biology Department, De La Salle University Manila, 2401 Taft Avenue, Manila 1004, Philippines \\ ${ }^{5}$ Faculty of Fisheries and Marine Science, Diponegoro University, Semarang 50275, Indonesia \\ ${ }^{6}$ Animal Biomedical and Molecular Biology Laboratory, Faculty of Veterinary Medicine, Udayana University Bali, \\ Jl Sesetan-Markisa 6, Denpasar, Bali 80225, Indonesia \\ ${ }^{7}$ Borneo Marine Research Institute, University Malaysia Sabah, Locked Bag 2073, 88400 Kota Kinabalu, Sabah, Malaysia \\ ${ }^{8}$ Marine Science Institute, University of the Philippines, Dilliman, Quezon City 1101, Philippines \\ ${ }^{9}$ Marine Fisheries Research Division, National Fisheries Research and Development Institute, 940 Quezon Avenue, \\ Quezon City 1103, Philippines \\ ${ }^{10}$ Faculty of Animal Sciences, Fisheries and Marine Science, The State University of Papua, Manokwari-West Papua 98314, Indonesia
}

Correspondence should be addressed to Kent E. Carpenter, kcarpent@odu.edu

Received 15 June 2010; Accepted 3 September 2010

Academic Editor: Robert J. Toonen

Copyright ( $) 2011$ Kent E. Carpenter et al. This is an open access article distributed under the Creative Commons Attribution License, which permits unrestricted use, distribution, and reproduction in any medium, provided the original work is properly cited.

Extreme concentration of marine biodiversity and exploitation of marine resources in the Coral Triangle pose challenges to biogeographers and resource managers. Comparative phylogeography provides a powerful tool to test biogeographic hypotheses evoked to explain species richness in the Coral Triangle. It can also be used to delineate management units for marine resources. After about a decade of phylogeographical studies, patterns for the Coral Triangle are emerging. Broad connectivity in some species support the notion that larvae have maintained gene flow among distant populations for long periods. Other phylogeographic patterns suggest vicariant events resulting from Pleistocene sea level fluctuations, which have, at least occasionally, resulted in speciation. Divergence dates ranging back to the Miocene suggest that changing land configurations may have precipitated an explosion of species diversification. A synthesis of the marine phylogeographic studies reveals repeated patterns that corroborate hypothesized biogeographic processes and suggest improved management schemes for marine resources.

\section{Introduction}

The Coral Triangle is well recognized as the global apogee of marine biodiversity, with species richness incrementally decreasing from this region eastward across the Pacific Ocean and westward across the Indian Ocean $[1,2]$. This center encompasses much of Indonesia, Malaysia, the Philippines, Brunei, Timor L'Este, Papua New Guinea, and the Solomon Islands and is also variously referred to as the East Indies Triangle (e.g., [3-5]), the Indonesian and Philippine Region [6], the Indo-Malay-Philippine Archipelago [7, 8], and a variety of other names [2]. It has also been referred to as 
the Indo-Australian Archipelago (e.g., $[9,10])$ although this is a misnomer for the Coral Triangle biodiversity hotspot, since it does not include Australia [1] and has geological origins transcending Eurasian and Indian-Australian tectonic elements [11]. In addition to its biodiversity reputation, the Coral Triangle is also unfortunately well known for peaks in threats to marine biodiversity, particularly for reefbuilding corals and coral reef fishes [12-14] and the need for improved marine resource management [1].

From a geological perspective, the Coral Triangle hotspot is relatively young [15]. Throughout the Paleogene ( $65-$ 23 mya), tropical ocean formed an essentially continuous belt around the globe, with the Atlantic and Pacific basins connected by the Tethys Sea. During much of this time, the global center of marine biodiversity was found in the western Tethys Sea, as indicated by fossil beds in what is now the Mediterranean Sea [15-17]. In the late Eocene, this center shifted east to what is now the Arabian Peninsula, with the initial collision of Africa and Eurasia and the rifting of the Arabian plate $[17,18]$. Continued west-to-east collision of Africa and Eurasia then constrained both of these hotspots, and finally closed off the Tethys Sea about 19 mya, and the center of biodiversity moved to its current position in the middle of the Indo-Pacific. A large component of biodiversity in the Coral Triangle must then consist of taxa that shifted their ranges from earlier centers of diversity [19-21] (see Harzhauser et al. [22] for a detailed example from the Tridacnidae).

Around the time that taxa from the diminishing Tethyan hotspots began to invade the Indo-Pacific, tectonic processes were producing more diversification in situ. Until the beginning of the Miocene about 23 mya, diversity within the Coral Triangle was surprisingly low across many taxa, ranging from zooxanthellate corals to mangroves ("The Paleogene Gap") $[16,17]$. At about this time, roughly coincident with the closure of the Tethys Sea, the Australian plate began to collide with island arcs in the Pacific, and the southeast margin of the Eurasian plate, dramatically altering surface circulation and effectively defining the modern basins of the Indian and Pacific Oceans [23]. Numerous phylogenetic studies of Indo-Pacific fish and gastropod taxa have found that most diversification occurred following this collision, during the Miocene [21, 24-27], and some have even found a distinct pulse of lineage diversification associated with the timing of the collision around 20 to 25 million years ago [20,28]. Thus, the initial formation of the complex Coral Triangle seascape in the middle of the Indo-Pacific appears connected to its high levels of biodiversity.

While the timing of the appearance of the much of the biodiversity of the Coral Triangle is apparent, the mechanisms that promoted the concentration of biodiversity remain unclear. Published conjectures on the evolutionary processes behind this biogeographic phenomenon are probably more numerous than any other single topic in marine biogeography (recently reviewed in Hoeksema [2]). The many hypotheses that attempt to explain the diversification and persistence of species can be generalized as accumulation, origin, overlap, and refuge hypotheses. The center of accumulation hypothesis suggests peripatric speciation on islands peripheral to the Coral Triangle [40, 41], followed by subsequent biogeographic dispersal and accumulation in the biodiversity hotspot. Alternatively, within the Coral Triangle, complicated marine currents and a history of sea level changes have variously connected and isolated marine populations. This complex interaction of geological and oceanographic processes could have promoted vicariance, and therefore the Coral Triangle has been proposed as a center of concentrated speciation that played a major role in the origin of the Indo-Pacific fauna $[6,42,43]$. The Coral Triangle is also an obvious area of potential admixture, or overlap, of diverse Indian and Pacific Ocean biotas such as geminate pairs of fishes $[3,44]$ and spiny lobsters $[45,46]$. This separation of Pacific and Indian Ocean biotas coincides with a major marine biogeographic break referred to as the Sunda Shelf Barrier [47, 48]. Perhaps most consequentially, the marine habitats of the Coral Triangle are highly diverse and extensive. The Sunda and Arafura shelves represent the largest tropical continental shelf area on earth [49]. This abundant and varied habitat has led many to hypothesize that the Coral Triangle is an area of relative refuge from extinction $[9,16,50]$.

Although hypotheses to explain the biodiversity of the Coral Triangle abound, the empirical work is limited and has not yet provided much clarity [51]. Traditional area cladogram tests have been attempted [4] but these are inconclusive: "It is possible that, with the addition of more taxa, additional patterns would emerge. Much more systematic work within the East Indies is required to resolve this problem" [52]. However, phylogenetic and phylogeographic tests of the above hypotheses also vary in their conclusions, seemingly dependent on the taxon, methodology and sampling strategy. Some taxa appear to show an abundance of peripatric speciation (e.g.) [53, 54]) while others seem to be diverging within the Coral Triangle (e.g., [29, 34, 55]). Many taxa show evidence that the extensive and varied habitats of the Coral Triangle help to lower their risk of extinction $[25,26]$ while there is molecular and paleontological evidence of frequent local extinctions on peripheral islands [56-60].

It has repeatedly been noted that the above hypotheses are not mutually exclusive-that all of the above processes are potentially building biodiversity in the Coral Triangle [ 7 , $8,51]$. A similar conclusion has been reached for the diversity center in the Caribbean [61]. This nonexclusivity, together with broadly similar predictions from each hypothesis and a flock of inconsistently applied definitions has often shed more heat than light on the Coral Triangle hotspot $[10,62]$. For example, the distinction between vicariant and peripatric speciation can be blurred, especially for marine species, because evolutionarily significant levels of gene flow among disjunct populations can be maintained by infrequent pulses of long-distance larval dispersal $[63,64]$. Perhaps what is needed is a new hypothetical framework that focuses on process rather than pattern (e.g., [65]).

At present, the most urgent question about Coral Triangle biodiversity is how it can be protected in the face of assorted anthropogenic alterations of the marine environment $[12,14]$. To do this, we will need to be able to 
precisely identify the evolutionary processes by which marine species in this region (1) diversify and (2) persist. Comparative phylogeography provides a means to test specific hypotheses regarding these processes $[66,67]$. Diversification and persistence are also the two main processes that underpin all hypotheses that attempt to explain the biodiversity of the Coral Triangle. In terms of diversification, what now seems clear is that many taxa that are recognized at the species level and above largely precede the sea-level fluctuations of the Pleistocene $[16,17,20,26,28]$; for possible exceptions see $[3,45]$. However, phylogeographic surveys of the Coral Triangle have uncovered numerous cryptic lineages that may represent newly formed (or forming) species [29, 33, 34, 53]. Perhaps by studying these recent speciation events in detail, we can better understand the tempo and mode of speciation in and around the Coral Triangle. In addition, the population boundaries delineated by concordant patterns in phylogeographic studies can serve as management units for fisheries management and marine protected area planning [40, 6871]. With regard to the persistence of marine species, the major evolutionary process to consider is gene flow. Marine habitats are generally patchy at many spatial scales, and this is particularly so for the reef fauna of the Coral Triangle. Most reef species ranges in this region span broad stretches $(\sim 1-500 \mathrm{~km})$ of pelagic ocean that can only be crossed by a pelagic larval stage. While genetic methodologies tend to be swamped by ecologically relevant levels of gene flow, they can be useful in detecting areas across which gene flow is low or nonexistent, or mediated by intermediate "steppingstone" populations $[34,71]$. Furthermore, coupling genetic connectivity studies with oceanographic models can help reveal barriers to larval dispersal and source (upstream) versus sink (downstream) population dynamics that will be helpful in establishing networks of marine protected areas [72]. Phylogeographic pattern relates primarily to genetic connectivity at evolutionary time scales and not necessarily to demographic connectivity at more ecological time scales [73-75]. However, the presence of shared phylogeographic breaks is evidence of demographic independence of phylogeographic regions. Phylogeography in the Coral Triangle is still very much in its nascent phase. Our purpose is to review phylogeographic patterns that have thus far been uncovered in the Coral Triangle and to determine if these patterns can be used to improve marine management schemes.

\section{Invertebrate Phylogeographic Pattern}

Early phylogeographic studies spanning the Coral Triangle region showed evidence of pronounced divergence among Pacific and Indian populations. Lavery et al. [76] first reported this pattern of Pacific-Indian Ocean divergence in the coconut crab, Birgus latro. Similar patterns were subsequently reported in the blue sea star, Linckia laevigata $[77,78]$, the tiger prawn, Penaeus monodon [79], and the crown of thorns sea star Acanthaster plancii [80], which has arguably fragmented into four distinct species [32]. Explanations for this pattern uniformly invoke vicariance among Pacific and Indian Ocean basins during Pleistocene low sea level stands. While these early studies provided the first glimpses of lineage diversification within and around the Coral Triangle, they often included only a few, if any, populations from within the Coral Triangle, limiting the inferences that could be drawn regarding evolutionary processes within the Coral Triangle.

Extending phylogeographic studies into the Coral Triangle have revealed a more complex picture of processes acting in this region. Early studies on Linckia laevigata indicated Pleistocene vicariance [77], and subsequent studies with more intensive sampling within the Coral Triangle support the notion of a Sunda Shelf barrier (Figure 1) but also show that the Coral Triangle is a region of admixture of Pacific and Indian Ocean lineages [30, 88]. Further genetic structuring of L. laevigata within the Coral Triangle has also been demonstrated in the western Philippines using allozymes [31]. Early allozyme genetic studies on $L$. laevigata revealed genetic differences between the Indian and Pacific Ocean populations dominated by two different color morphs: royal blue morph in the Western Pacific and an orange or apricot morph in the Indian Ocean [78]. Williams [89] demonstrated that orange and blue morphs shared the same mitochondrial DNA. However, allozyme and COI nucleotide sequence analysis suggested genetic differentiation between sympatric blue and orange color morphs found in the Kalayaan Island Group in western Philippines [90]. Moreover, there was significant fine-scale genetic structure among populations of the both color morphs in the South China Sea and Sulu Sea. Crandall et al. [30] showed evidence of regional isolation of L. laevigata in Cenderawasih Bay, a phylogeographic break in eastern Indonesian that is seen in another sea star, Protoreaster nodosus.

The first phylogeographic studies to focus intensively within the Coral Triangle examined the mantis shrimp, Haptosquilla pulchella $[91,92]$. The initial study indicated strong population genetic breaks between the Lesser and Greater Sunda Islands and populations to the north [91]. Expanding the range of the mantis shrimp study eastward [39] indicated that an additional population break for H. pulchella transects the Bird's Head region of Papua New Guinea (Figure 1). This led to a hypothesis that the oceanographic feature referred to as the Halmahera Eddy may serve as a barrier to larval dispersal westward into the Celebes, Molucca, and Banda Seas [29]. This eddy is a result of the New Guinea Coastal Current (an arm of the Southern Equatorial current) interacting with the Equatorial Counter Current [39] (Figure 1). The resulting eddy limits east to west water transport across the Molucca Sea, presumably limiting larval dispersal and gene flow as well. Phylogeographic data from two additional mantis shrimp species [29], Haptosquilla glyptocercus and Gonodactylinus viridis as well as 10 additional species of stomatopod [Barber et al., in review] corroborate an eastern Indonesian population break east and west of Halmahera and also a break near the southern Sunda Shelf (Figure 1). While these studies as well as earlier work on Birgus latro and Penaeus monodon suggest that genetic structure in the Coral Triangle is a common feature of crustaceans, work on the symbiotic shrimp, Periclimenes soror, shows no evidence of structure across the Coral 


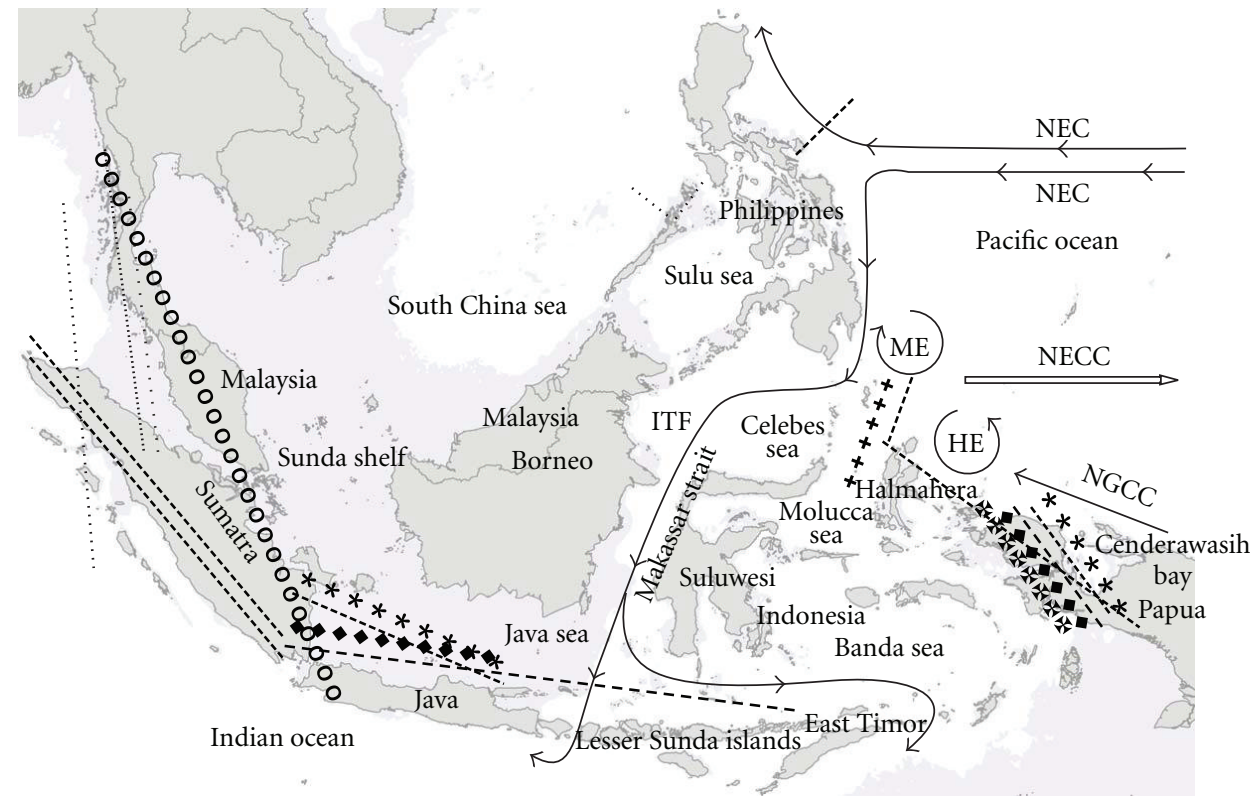

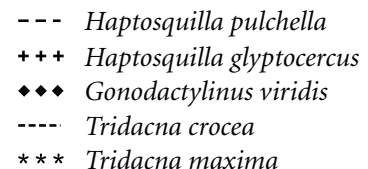

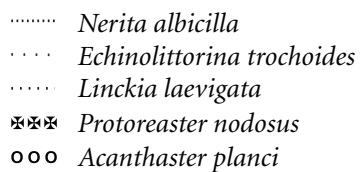

Figure 1: Major oceanographic surface currents and phylogeographic breaks in the Coral Triangle inferred from relative frequency pie chart figures of highly divergent clades, lineages, or haplotypes from published papers on invertebrates (Haptosquilla pulchella [29], Haptosquilla glyptocercus [29], Gonodactylinus viridis [29], Linckia laevigata [30, 31], Protoreaster nodosus [30], Acanthaster planci [32], Nerita albicilla [33], Tridacna crocea [34-36], Tridacna maxima [37], and Echinolittorina trochoides [38]). HE: Halmahera Eddy, ME: Mindanao Eddy, ITF : Indonesian Throughflow, NEC: Northern Equatorial Current, NECC : Northern Equatorial Counter Current, and NGCC: New Guinea Coastal Current (after Schiller [39]).

Triangle, despite strong phylogeographic structure in their host sea stars, Linckia laevigata and Protoreaster nodosus [30].

Studies of both bivalves and gastropods reveal population breaks across the Coral Triangle. Independent studies on the giant boring clam $[34,35]$, Tridacna crocea show phylogeographic breaks at the Sunda Shelf and in eastern Indonesian (Figure 1). On the eastern Philippine seaboard, north-south genetic structure broadly concordant with the bifurcation of the Northern Equatorial Current as well as significant fine-scale genetic differentiation was found for T. crocea populations [36]. Similarly, fine-scale genetic structuring in T. crocea populations in the shelf and shoal reefs of western Philippines has been demonstrated using allozymes [31]. Another giant clam, Tridacna maxima, shows a deep phylogenetic break in the Java Sea, between Eastern and Western Indonesia [37]. The periwinkles, Echinolittorina trochoides, Echinolittorina vidua [38], and Nerita albicilla [33], also show population breaks that correspond to the western Sunda Shelf Barrier (Figure 1). However, as with sea stars, this pattern is absent in the parasitic gastropod, Thyca crystallina, even though there is strong structure in its host, Linckia laevigata $[30,88]$. Additional evidence of structure within the Coral Triangle comes from limpets of the Patelloida profunda group [93] and the abalone Haliotis asinina [94]. The former study showed clades associated with Pacific and Indian Oceans, although the age of these lineages date back to the Miocene, suggesting a much deeper history to the patterns in this group.

Studies on additional invertebrates provide further evidence of population structure across the Coral Triangle. Regional structure is seen in the barnacle Chthamalus malayensis [95], in the coral reef sponge Leucetta chagosensis [81], and the scleractinian coral Heliofungia actiniformis [96]. However, sampling was insufficient to show exactly where these genetic breaks occurred in the Coral Triangle. Regional phylogeographic breaks were not present in two species of reef-building corals, Pocillopora damicornis and Seriatopora hystrix, although high levels of genetic divergence among many populations were observed [97].

\section{Fish Phylogeographic Pattern}

Tests of phylogeographic pattern using marine fish have varied spatial coverage across the Coral Triangle. Perrin and Borsa [98] demonstrated an apparent population break between Sulawesi and Borneo with the nearshore pelagic Indian Scad, Decapterus russelli (Figure 2), but the only sample site in eastern Indonesia was on northwestern 
Sulawesi. Ablan [99] suggested four separate management units based on population data from Dascyllus trimaculatus [82] and Thalossoma hardwickii [83] corresponding to the Sunda Shelf, the South China Sea, the Pacific Ocean, In contrast to invertebrate and the Philippines plus eastern Indonesia. Leray et al. [84] also demonstrated a broad geographic break consistent with a Sunda Shelf barrier for D. trimaculatus. Drew and Barber [87] demonstrated a strong genetic break consistent with the western Sunda Shelf Barrier in the Lemon Damsel Pomacentrus moluccensis. Lourie et al. [85] studied four species of seahorse around Southeast Asia and found population breaks within the Philippines, north-south and east-west across the Coral Triangle, and corresponding to the western Sunda Shelf Barrier (Figure 2). Timm et al. [55] tested connectivity with the False Clown Anemonefish, Amphiprion ocellaris, and found population breaks corresponding to the southern Sunda Shelf Barrier, easternmost Indonesia, and a broad north-south break (Figure 2). Based on allozyme analysis, Magsino et al. [86] demonstrated a phylogeographic break in Siganus fuscescens consistent with the Northern Equatorial Current Bifurcation in eastern Philippines (Figure 2). This population break in S. fuscescens was further validated by analyses of the mtDNA control region that also suggests isolation of the South China Sea basin and fine-scale structuring within the South China Sea and southern Philippine Sea [100]. Although phylogeographic pattern in fishes supports Sunda Shelf, easternmost Indonesia breaks, and the northeastern and southeastern Philippine break consistent with some invertebrates, corroboration is lacking for other phylogeographic breaks.

Phylogeographic structure has been detected in a number of fish species studied widely across the Indo-Pacific with limited samples within the Coral Triangle and therefore could not detect breaks within the Coral Triangle. These include the surgeonfish Acanthurus triostegus [101], the milkfish Chanos chanos [102], the parrotfish Chlorurus sordidus [103], and the snapper Lutjanus fulvus [104]. High levels of microspatial genetic structure have been detected in the Banggai cardinalfish, Pterapogon kauderni, but this is limited to a small area in eastern Indonesia [105-107]. Other studies sampled disparate sites or limited genes within the coral triangle and broadscale phylogeographic breaks cannot be inferred. These include the clownfish Amphiprion ocellaris [108], the wrasse Thalossoma hardwicki [83], the snapper Pristipomoides multidens [109], the scad mackerel Decapterus russelli [110], and the Spanish mackerel Scomberomorus commerson [111].

\section{Species without Apparent Phylogeographic Breaks across the Coral Triangle}

In addition to evident barriers to gene flow across the Coral Triangle, a number of species exhibit apparent lack of phylogeographic breaks across the region. This includes the sea urchins Eucidaris, Diadema, and Tripneustes [112114], the marine snails Echinolittorina reticulata [38] and Nerita plicata [33], the nearshore pelagic scads Decapterus macrosoma and Decapterus macarellus [115], the trumpetfish Aulostomus chinensis [116], three species of surgeonfishes of the genus Naso [117, 118], and the Eastern Little Tuna Euthynnus affinis [119]. Although sites were not sampled within the Coral Triangle, the Bigscale Soldierfish, Myripristis berndti, also apparently does not show phylogeographic structure across the Indo-West Pacific [120]. The lack of phylogeographic structure across the Coral Triangle is surprising given Pleistocene fluctuations in sea level that potentially restricted gene flow. These species may have continued to successfully disperse through the Coral Triangle during periods of glacial maxima, reestablished gene flow quickly after glacial maxima, lost divergent lineages, undergone selective sweeps, or simply did not span the Coral Triangle during glacial periods $[30,121]$. One other possibility is that the genetic markers or sample sizes used were not adequate to detect population structure.

\section{Concordant Phylogeographic Pattern}

The numerous marine phylogeographic patterns in the Coral Triangle, above, strongly support a western Sunda Shelf Barrier. The Sunda Shelf was emergent during Pleistocene low sea level stands, which would have limited larval transport and genetic exchange among Pacific and Indian Ocean populations on either side of the shelf, promoting lineage diversification. Similarly, the increasing numbers of studies focused within the Coral Triangle are beginning to corroborate an eastern Indonesia barrier in vicinity of the Mindanao and Halmahera Eddies (Figures 1 and 3) where physical oceanographic processes constrain water exchange, and thus larval transport and gene flow. However, the number of studies in this region is still limited. Furthermore, sample coverage is particularly sparse in some areas, especially in the Philippines, Malaysia, Papua New Guinea, the Solomon Islands, East Timor and the Borneo, Sumatra, and Banda Sea regions of Indonesia, making it difficult to corroborate barriers to lineage diversification elsewhere.

Phylogeographic patterns in invertebrates (Figure 1) are highly concordant in the western and southern Coral Triangle but coverage of sample sites in the northern, eastern, and southeastern Coral Triangle is sparse. Six species exhibit barriers to gene flow corresponding to western peninsular Malaysia and western Sumatra. This population level break closely follows the Sunda Shelf Barrier, a major biogeographic break between Indian and Pacific Ocean biotas [47]. The three concordant phylogeographic breaks along the southern edge of the Sunda Shelf and the Lesser Sunda Island chain also correspond to this barrier. However, the population breaks occur in the region north of Java in the Java Sea [37, 91] and between the Lesser Sunda Islands and Sulawesi [29]. Hypotheses relating to this northern orientation of phylogeographic breaks in the southern region of the Sunda Shelf Barrier still need to be formulated and tested.

Seven species of invertebrates show phylogeographic breaks in eastern Indonesia consistent with the Bird's head region of New Guinea, specifically, Cenderawasih Bay (see [29], Barber et al. in review). Seven species of invertebrates 


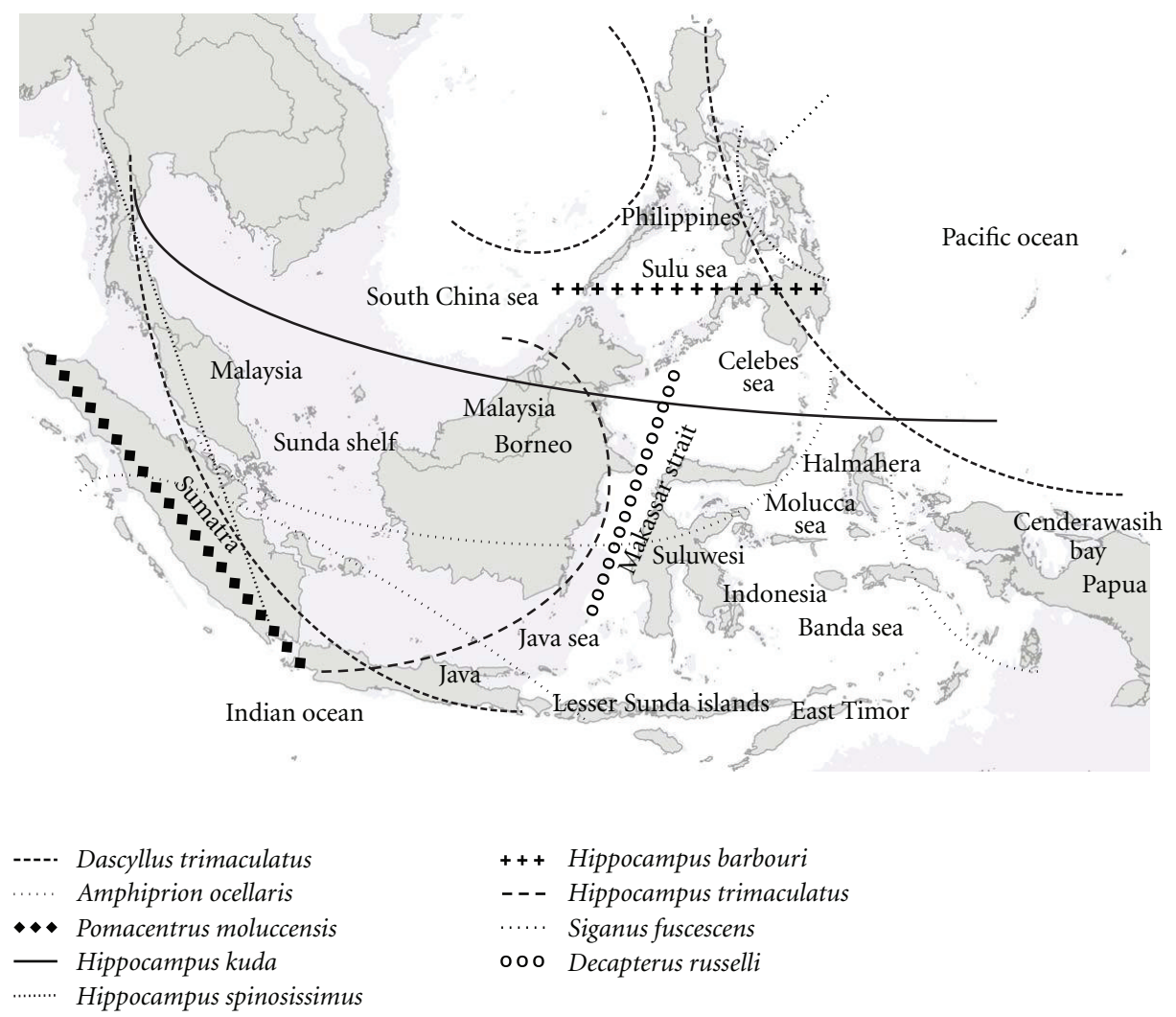

Figure 2: Phylogeographic breaks in the Coral Triangle inferred from relative frequency pie chart figures of highly divergent clades, lineages or haplotypes from published papers on fishes (Decapterus russelli [81], Dascyllus trimaculatus + Thalossoma hardwickii [82-84], Hippocampus barbouri [85], Hippocampus kuda [85], Hippocampus spinosisssimus [85], Hippocampus trimaculatus [85], Amphiprion ocellaris [55], Siganus fuscescens [86], and Pomacentrus moluccensis [87].

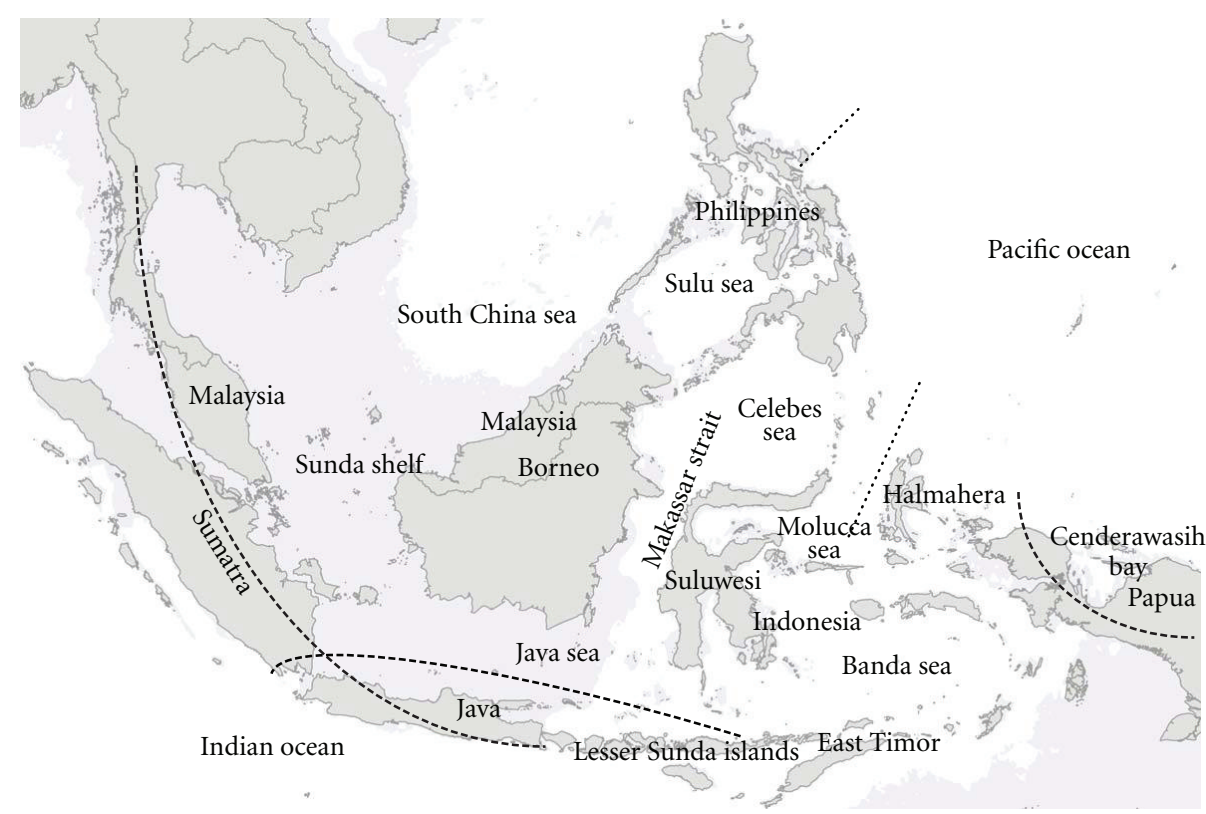

----. 3 or more concordant phylogeographic breaks

…. 2 concordant phylogeographic breaks

FIGURE 3: Generalized position of concordant phylogeographic breaks. 
also show population structure in this region but more consistent with the area of Halmahera (see [30, 34], Barber et al. in review), and six species show divergence among populations among the Western Papua, Indonesia, and Papua New Guinea [Barber et al. in review].

In contrast to invertebrate phylogeography in the Coral Triangle, patterns from fishes are not highly concordant. Population breaks in a seahorse [85], a clownfish [55], the Lemon Damsel [87], and the Threespot Dascyllus [84] corroborate the Sunda Shelf Barrier seen in invertebrates. Similarly, data from the clownfish Amphiprion ocellaris corroborates an eastern Indonesian barrier (see [55], Barber et al. unpublished data). While phylogeographic concordance in fishes is not as strong as in invertebrates, this pattern likely has both methodological as well as biological origins.

The apparent lack of consistent concordance in fish phylogeographic patterns in comparison to invertebrates is almost certainly partially an artifact of sample coverage. Several of the recent invertebrate studies are part of coordinated efforts to intensely sample multiple codistributed taxa across Indonesia [29, 30, 33-35], while others focus sampling more widely across the Pacific and Indian Oceans $[32,34,38]$. In contrast, fish sampling in the Coral Triangle has largely been restricted to a specific region in the Philippines or in Indonesia $[86,98]$ has been widespread across Southeast Asia but with uneven sample coverage either within Indonesia or within the Philippines [55, 85, 99], or corresponds to a wide Indo-Pacific coverage [84, 87]. The varied levels of concordance between different sampling programs highlights the importance of systematic sampling of multiple species across broad spatial scales in order to accurately identify phylogeographic boundaries in this region. It is likely that as more coordinated sampling efforts are conducted on fish in this region that more examples of concordance will emerge, improving our understanding of the evolution of biodiversity in the Coral Triangle.

While there will certainly be more examples of concordance in fish taxa, the intrinsic differences in life histories in invertebrate and fish will likely result in more examples of phylogeographic discordance in fish than invertebrates. The characteristics and interplay of mobility of larvae and adults are typically different in invertebrates versus fishes. With the exception primarily of crustaceans, invertebrate larvae are poor horizontal swimmers [122] although they can influence their dispersal through active vertical swimming. Consequently, dispersal and recruitment in invertebrates may generally be more passive and more predictable from ocean circulation patterns than for fishes although the similarities in phylogeographic structure in the giant clam (Tridacna crocea) and clownfish (Amphiprion ocellaris) suggest that this may not be the case. Fish larvae, on the other hand, are generally more active and have been shown to return to their natal population and restrict genetic mixing between populations $[123,124]$. This reduces effective population size and allows faster, stochastic sorting and can result in an unpredictable mosaic of population structure. This is exemplified in Amphiprion [55] and Hippocampus [85] that have relatively short larval dispersal durations for fish (e.g., 10-14 days in Amphiprion). All the invertebrates and nearly all the fishes reviewed in this study show limited mobility and/or site specificity as adults and, therefore, differences in genetic structure are expected from differences in larval mobility and biogeographic history. Exceptions to this are pelagic and wide-ranging demersal fishes and cephalopods. Dispersal and hence phylogeographic pattern in these forms can be heavily influenced by adult mobility except when localized spawning aggregations may influence genetic patterns. In this paper, only the nearshore pelagic scad, Decapterus russelli, is highly mobile as an adult and this species showed a unique phylogeographic break (Figure 2). Two other nearshore scad species showed no genetic structure in this area [115], which is consistent with low levels of molecular divergence found in other species of pelagic fishes [121].

\section{Management Implications}

6.1. Concordant Phylogeographic Breaks Suggest Broad Management Units. Phylogeographic studies in the Coral Triangle are still at an early stage but existing concordant phylogeographic breaks suggest broad management units across the western and southern Coral Triangle (Figures 3 and 4). These units appear robust because they are corroborated across multiple taxa and multiple loci [47, 69-72]. The Sunda Shelf biogeographic barrier [47], resoundingly corroborated by phylogeographic studies (Figure 3), suggests natural management divisions between east and west Sumatra and between the Andaman Sea and the Gulf of Thailand (Figure 4). A concordant phylogeographic break to the north of Java and the Lesser Sunda Islands suggest that these constitute a natural management unit. A large portion of eastern Indonesia that includes most of the seas east of Borneo appears to be a natural management unit. Halmahera to the westernmost Bird's Head region of Papua also appears to be a management unit that may either be discrete or a subunit of an eastern Indonesia management unit. Further phylogeographic studies are needed to corroborate this. This division supports ecosystem-based fisheries management efforts in the Bird's Head Seascape around Raja Ampat [125]. Populations around Cenderawasih Bay are typically divergent from those to the west, and therefore the northern Papua region could be managed separately. In eastern Philippines, two species corroborate a phylogeographic break that corresponds with the Northern Equatorial Current Bifurcation [36, 86], and this suggests that northeastern and southeastern Philippines should be treated as separate management units.

6.2. Concordance of Phylogeographic Pattern with Currents and Ecoregions. Marine management schemes that utilize population genetic data are considered stronger if combined with supporting evidence from oceanographic data and other supporting approaches [72]. The dominant surface ocean circulation features in Indonesia in terms of volume of transport [39] are the Indonesian Throughflow from the Pacific, and the Halmahera and Mindanao eddies that feed the Northern Equatorial Counter-Current (Figure 1). The Halmahera Eddy was postulated as the main reason for phylogeographic breaks in eastern Indonesia [29]. However, 


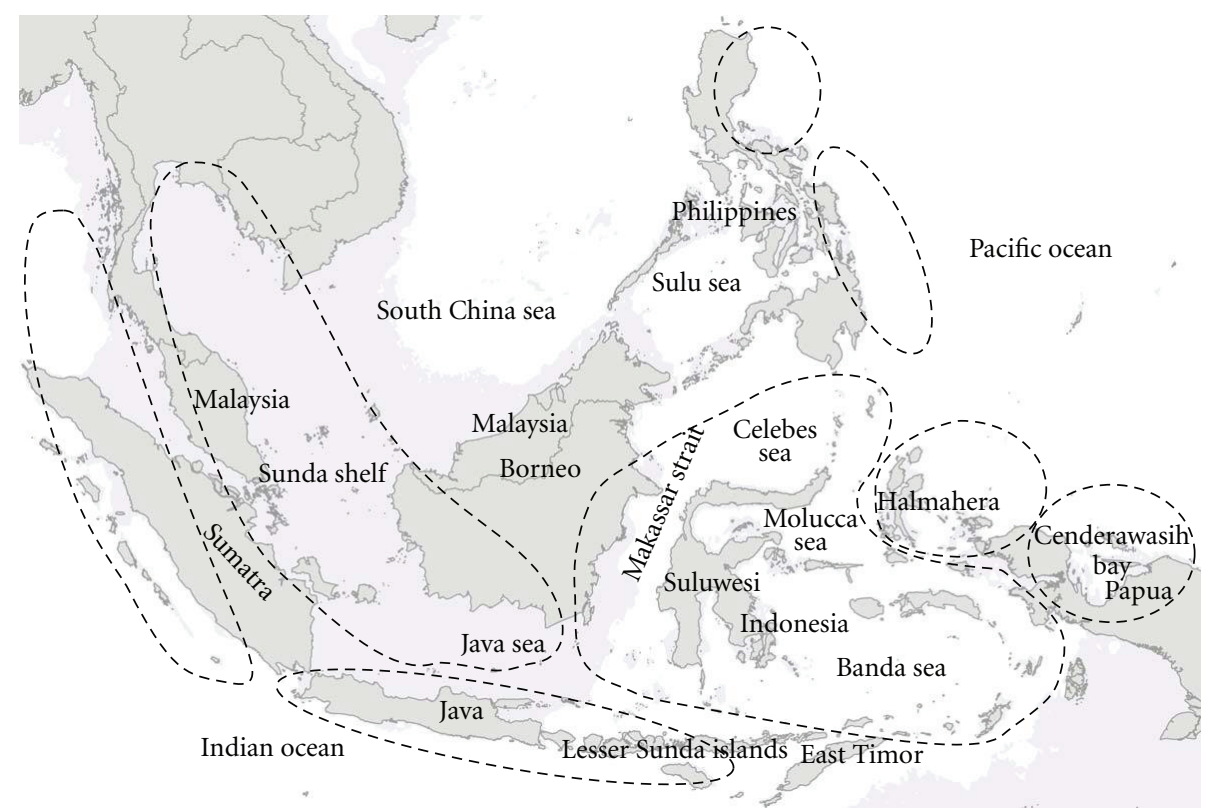

FIgURE 4: Approximate minimum management units inferred from concordant phylogeographic breaks. Although no phylogeographic break was evident east to west across the Java Sea, we assume that the Sunda Shelf biota is distinct from eastern Indonesia and these warrant their own management strategy.

with recent ocean circulation reanalyses it is likely that the Mindanao Eddy also plays a significant role in eastern Indonesia depending on the monsoon season [39]. Both these eddies, together with the concordant phylogeographic breaks, support the idea of delineating separate management units in eastern Indonesia. The predominantly separate ocean circulation between the Sunda Shelf and the Indian Ocean also supports the use of the Sunda Shelf phylogeographic breaks as demarcating management units. The southern Sunda Shelf break north of Java and the Lesser Sunda Islands is not strongly supported by ocean circulation. The Indonesian Throughflow suggests a strong north to south surface flow from the Makassar Straits across the Java Sea during the Southeast Monsoon [39]. However, during the Northwest Monsoon this flow is weak and the predominant current is east to west in the Java Sea that could restrict gene flow with populations to the north. While the phylogeographic patterns in this region may have historical origins, their persistence through contemporary oceanographic conditions strongly suggests that gene flow must be severely limited among these regions [29] arguing for the ecological independence of these regions.

Concordant phylogeographic pattern in the Philippines corresponds with the bifurcation of the Northern Equatorial Current. However, these are corroborated by only two published studies in the eastern Philippines $[36,86]$. The mean latitude of the transition of the Northern Equatorial Current into separate northern and southern directed boundary currents has been reported as high as $15.5^{\circ} \mathrm{N}$ [126], but more recently it has been reported at $13.3^{\circ} \mathrm{N}$, although this fluctuates to $14.0^{\circ} \mathrm{N}$ in January and to $12.5^{\circ} \mathrm{N}$ in July [127].

Additional phylogeographic and oceanographic studies are needed to refine management units across the Coral
Triangle. Particularly useful will be studies that integrate estimates of genetic connectivity with predictions from computer models of connectivity based on physical oceanography so that the impact of physical oceanography on realized dispersal and connectivity can be rigorously examined in a quantitative, rather than qualitative, fashion.

Marine ecoregions based on floral and faunal composition, major physical and biological oceanographic features and expert opinion have also been proposed as a means of delineating units of marine management $[1,128]$. Coupling these approaches with phylogeographic breaks may strengthen management. However, on the surface there appears to be limited agreement between units suggested by phylogeographic breaks and ecoregions proposed from metadata analysis and expert opinion [128] or patterns of coral biodiversity [1]. Proposed ecoregions do separate the Sunda Shelf from the Indian Ocean and both north and south Lesser Sunda Islands are independent units. In addition, ecoregions corroborate phylogeographic breaks separating Eastern Indonesia. Aliño and Gomez [129] also recognize northeastern and southeastern biogeographic regions corresponding to the Northern Equatorial Current Bifurcation. Coral biodiversity also suggests Cenderawasih Bay as a separate unit.

The correspondence between some of the marine ecoregions and published phylogeographic breaks suggests that some ecoregions are indeed functioning as ecologically independent units. However, there are far fewer recognized phylogeographic breaks than ecoregions. This result could be interpreted that the marine ecoregion approach is flawed. Instead, this result most likely reflects the fundamental difference in the methods used to determine ecoregions and the genetic connectivity and the limits of genetic methods 
to recover ecological independence among regions. Genetic patterns evolve over periods of hundreds and thousands of years. However, small levels of gene flow that can have a profound impact on genetic patterns may be inconsequential demographically [73-75]. Thus, while the presence of strong phylogeographic breaks confirms the demographic independence of two spatially distinct populations, the absence of phylogeographic structure does not necessarily indicate that two populations are connected by ecologically relevant levels of larval dispersal. It remains to be seen whether more rapidly evolving genetic markers can provide additional support to the proposed marine ecoregions in the Coral Triangle. However, the recovery of multiple phylogeographic breaks in the region of Cenderawasih Bay does indicate the demographic independence of some species in this region, suggesting that the boundaries of these ecoregions may need to be modified.

6.3. Future Directions for Management Strategy. While concordant phylogeographic patterns exist for Indonesia and eastern Philippines, data are insufficient to draw any broad-scale patterns elsewhere in the Coral Triangle, particularly for most of the Philippines and Malaysia. Corroborated phylogeographic breaks are also largely incomplete at finer scales within the Coral Triangle, although some fine-scale population structure, such as around Palawan [31], has been reported. Most fine-scale studies to date have largely focused on individual countries, rather than the entire Coral Triangle. As additional studies are conducted, more unique phylogeographic regions and management areas may be identified. Similarly, more connections among nations may also be identified. For example data for giant clams (DeBoer et al. in review) and stomatopods (Barber et al. in review) both indicate high genetic similarity between Philippine and Central Indonesian populations, indicating that management planning will likely need to span international borders.

The recovery of concordant phylogeographic breaks indicates the evolutionary, and thus demographic, independence among regions of the Coral Triangle. These results suggest management units although it should be recognized that these are general guidelines as many species do not follow the general pattern. The spatial scales of genetic structuring depend on the life history of species and local factors that affect larval transport and recruitment success. Genetic patterns are also a result of many stochastic processes and changing physical processes may result in different phylogeographic pattern. As such, it is unclear whether lack of corresponding phylogeographic breaks in some taxa are the result of unique biological factors that should be incorporated into management plans or are the result of stochastic genetic processes, despite the physical environment having the same impact on codistributed species. Given this uncertainty and the range of responses across multiple taxa in the Coral Triangle, species-specific management interventions within large-scale management units should be complemented by networks of marine protected areas that take into consideration representative habitat types to enhance protection of species and genetic diversity of highly exploited species. These nested scales of management units reflect the large-scale (evolutionary time scales or vicariance) versus small-scale (ecological and isolation by distance) factors influencing phylogeographic pattern.

\section{Conclusions}

Phylogeography in the Coral Triangle is young, even in comparison to the rest of this burgeoning field. Most of the studies reviewed here were published in the last ten years, and most are limited to inference from mitochondrial genes. However, the abundance of cryptic mitochondrial lineages identified thus far strongly suggests not only that biodiversity in this global marine hotspot is even higher than expected, but also that new species are forming as we write. Broadly speaking, the Coral Triangle may represent the world's largest suture zone $[130,131]$, in which divergent genomes from Pacific and Indian Oceans are periodically brought back into contact by rising sea levels [33, 132, 133]. Confirmation awaits results from nuclear loci, but we can readily see evidence of a suture zone in high numbers of hybrid reef fish observed at Christmas and Cocos Islands off the coast of Sumatra [133, 134], and the broad and parallel (but not identical) clines in color morphs, allozymes and mtDNA clade frequencies in Linckia laevigata [30, 78, 135]. The location of mitochondrial breaks reviewed here may not then represent the precise location of an allopatric barrier, but the boundary at which divergent mitochondrial genomes were reunited as they reexpanded with rising sealevels $[136,137]$. Whether the observed phylogenetic breaks have actually resulted from allopatric speciation will depend on the effective population size and ecological characteristics of each lineage (see Crandall et al. [33] for two contrasting examples).

Where did coral reef taxa find refugia during periods of lowered sea levels and glacial climactic regimes [138]? How did rising sea levels and expanding populations affect genetic diversity and local adaptation [137]? Were the resoundingly corroborated phylogeographic breaks present today, also present during previous glacial minima? Will additional studies corroborate these breaks and potentially reveal additional phylogeographic breaks? Did these phylogeographic breaks lead to lineage diversification and contribute to the extreme diversity found in the Coral Triangle? These questions and others can only be addressed with data from multiple unlinked genetic markers. Next generation sequencing technologies will soon provide relatively inexpensive access to genetic information from across the genome of many codistributed species [139]. This influx of data, in combination with information from ecological niche models [140] and biophysical models of larval dispersal [141], will allow us to address these questions with increasing accuracy.

Future studies of population genetics in the Coral Triangle will also further address management questions in this oceanographic, geologic, and biogeographic complex archipelago. Further delineation of population structure will allow management decisions to be made within a biological framework rather than in an administrative framework of convenience that may not be as effective. Assignment tests 
and parentage analysis are already helping to provide empirical estimates of larval dispersal within networks of marine-protected areas [142, 143]. The application of a nested small-scale management area within large scale management area approach to applied phylogeography can help preserve the rich resources and biodiversity of the Coral Triangle for future generations.

\section{Acknowledgments}

The authors thank the organizers of the Indo-Pacific Fish Conference held in Freemantle, Western Australia in 2009 for the invitation to K. E. Carpenter to present the talk that forms the basis for this paper and to Rob Toonen for the invitation to include this review in this special issue. They thank Mark Erdmann and Conservation International for their support in collecting samples and for genetic analyses of specimens from Indonesia. This work was completed with support from NSF OISE-0730256 to K. E. Carpenter and P. H. Barber and NSF OCE-0349177 to P. H. Barber. They thank Emilie Stump for help with illustrations, Jonnell Sanciangco for producing the base map, and two anonymous reviewers for helpful suggestions for improvement of the paper.

\section{References}

[1] J. E. N. Veron, L. M. DeVantier, E. Turak et al., "Delineating the coral triangle," Galaxea, vol. 11, no. 2, pp. 91-100, 2009.

[2] B. W. Hoeksema, "Delineation of the Indo-Malayan centre of maximum marine biodiversity: the coral triangle," in Biogeography, Time and Place: Distributions, Barriers and Islands, W. Renema, Ed., chapter 5, pp. 117-178, Springer, Dordrecht, The Netherlands, 2007.

[3] J. E. Randall, "Zoogeography of shore fishes of the IndoPacific region," Zoological Studies, vol. 37, no. 4, pp. 227-268, 1998.

[4] F. Santini and R. Winterbottom, "Historical biogeography of Indo-western Pacific coral reef biota: is the Indonesian region a centre of origin?" Journal of Biogeography, vol. 29, no. 2, pp. 189-205, 2002.

[5] J. C. Briggs, "Extinction and replacement in the Indo-West Pacific Ocean," Journal of Biogeography, vol. 26, no. 4, pp. 777-783, 1999.

[6] C. Mora, P. M. Chittaro, P. F. Sale, J. P. Kritzer, and S. A. Ludsin, "Patterns and processes in reef fish diversity," Nature, vol. 421, no. 6926, pp. 933-936, 2003.

[7] D. R. Bellwood and P.C. Wainwright, "The history and biogeography of fishes on coral reefs," in Coral Reef Fishes, P. F. Sale, Ed., pp. 5-32, Academic Press, New York, NY, USA, 2002.

[8] K. E. Carpenter and V. G. Springer, "The center of the center of marine shore fish biodiversity: the Philippine Islands," Environmental Biology of Fishes, vol. 72, no. 4, pp. 467-480, 2005.

[9] D. R. Bellwood and T. P. Hughes, "Regional-scale assembly rules and biodiversity of coral reefs," Science, vol. 292, no. 5521, pp. 1532-1534, 2001.

[10] D. R. Bellwood and C. P. Meyer, "Endemism and evolution in the Coral Triangle: a call for clarity," Journal of Biogeography, vol. 36, no. 10, pp. 2010-2012, 2009.
[11] R. Hall, "The plate tectonics of Cenozoic SE Asia and the distribution of land and sea," in Biogoegraphy and Geological Evolution of SE Asia, R. Hall and J. D. Holloway, Eds., pp. 99131, Backhuys Publishers, Leiden, The Netherlands, 1998.

[12] L. Burke, L. Selig, and M. Spalding, Reefs at Risk in Southeast Asia, The World Resources Institute, Washington, DC, USA, 2002.

[13] C. M. Roberts, C. J. McClean, J. E. N. Veron et al., "Marine biodiversity hotspots and conservation priorities for tropical reefs," Science, vol. 295, no. 5558, pp. 1280-1284, 2002.

[14] K. E. Carpenter, M. Abrar, G. Aeby et al., "One-third of reef-building corals face elevated extinction risk from climate change and local impacts," Science, vol. 321, no. 5888, pp. 560-563, 2008.

[15] G. J. Vermeij, "Community assembly in the sea: geologic history of the living shore biota," in Marine Community Ecology, M. Bertness, S. D. Gaines, and M. E. Hay, Eds., Sinauer Associates, Sunderland, Mass, USA, 2001.

[16] M. E. J. Wilson and B. R. Rosen, "Implications of paucity of corals in the Paleogene of SE Asia: plate tectonics or Centre of Origin-," in Biogeography and Geological Evolution of SE Asia, R. Hall and J. D. Holloway, Eds., pp. 165-195, Backhuys Publishers, Leiden, The Netherlands, 1998.

[17] W. Renema, D. R. Bellwood, J. C. Braga et al., "Hopping hotspots: global shifts in marine biodiversity," Science, vol. 321, no. 5889, pp. 654-657, 2008.

[18] M. Harzhauser, A. Kroh, O. Mandic et al., "Biogeographic responses to geodynamics: a key study all around the OligoMiocene Tethyan Seaway," Zoologischer Anzeiger, vol. 246, no. 4, pp. 241-256, 2007.

[19] C. C. Wallace and B. R. Rosen, "Diverse staghorn corals (Acropora) in high-latitude Eocene assemblages: implications for the evolution of modern diversity patterns of reef corals," Proceedings of the Royal Society Biological Sciences, vol. 273, no. 1589, pp. 975-982, 2006.

[20] M. A. Frey and G. J. Vermeij, "Molecular phylogenies and historical biogeography of a circumtropical group of gastropods (Genus: Nerita): implications for regional diversity patterns in the marine tropics," Molecular Phylogenetics and Evolution, vol. 48, no. 3, pp. 1067-1086, 2008.

[21] M. A. E. Malaquias and D. G. Reid, "Tethyan vicariance, relictualism and speciation: evidence from a global molecular phylogeny of the opisthobranch genus Bulla," Journal of Biogeography, vol. 36, no. 9, pp. 1760-1777, 2009.

[22] M. Harzhauser, O. Mandic, W. E. Piller, M. Reuter, and A. Kroh, "Tracing back the origin of the indo-pacific mollusc fauna: basal tridacninae from the oligocene and miocene of the sultanate of oman," Palaeontology, vol. 51, no. 1, pp. 199213, 2008.

[23] R. Hall, "Cenozoic geological and plate tectonic evolution of SE Asia and the SW Pacific: computer-based reconstructions, model and animations," Journal of Asian Earth Sciences, vol. 20, no. 4, pp. 353-431, 2002.

[24] S. O. Klanten, L. van Herwerden, J. H. Choat, and D. Blair, "Patterns of lineage diversification in the genus Naso (Acanthuridae)," Molecular Phylogenetics and Evolution, vol. 32, no. 1, pp. 221-235, 2004.

[25] S. T. Williams and D. G. Reid, "Speciation and diversity on tropical rocky shores: a global phylogeny of snails of the genus Echinolittorina," Evolution, vol. 58, no. 10, pp. 22272251, 2004 
[26] P. H. Barber and D. R. Bellwood, "Biodiversity hotspots: evolutionary origins of biodiversity in wrasses (Halichoeres: Labridae) in the Indo-Pacific and new world tropics," Molecular Phylogenetics and Evolution, vol. 35, no. 1, pp. 235253, 2005.

[27] C. I. Read, D. R. Bellwood, and L. van Herwerden, "Ancient origins of Indo-Pacific coral reef fish biodiversity: a case study of the leopard wrasses (Labridae: Macropharyngodon)," Molecular Phylogenetics and Evolution, vol. 38, no. 3, pp. 808$819,2006$.

[28] S. T. Williams and T. F. Duda Jr., "Did tectonic activity stimulate Oligo-Miocene speciation in the Indo-West Pacific?" Evolution, vol. 62, no. 7, pp. 1618-1634, 2008.

[29] P. H. Barber, M. V. Erdmann, and S. R. Palumbi, "Comparative phylogeography of three codistributed stomatopods: origins and timing of regional lineage diversification in the coral Triangle," Evolution, vol. 60, no. 9, pp. 1825-1839, 2006.

[30] E. D. Crandall, M. E. Jones, M. M. Muñoz, B. Akinronbi, M. V. Erdmann, and P. H. Barber, "Comparative phylogeography of two seastars and their ectosymbionts within the Coral Triangle," Molecular Ecology, vol. 17, no. 24, pp. 5276-5290, 2008.

[31] M. A. Juinio-Meñez, R. M. Magsino, R. Ravago-Gotanco, and E. T. Yu, "Genetic structure of Linckia laevigata and Tridacna crocea populations in the Palawan shelf and shoal reefs," Marine Biology, vol. 142, no. 4, pp. 717-726, 2003.

[32] C. Vogler, J. Benzie, H. Lessios, P. Barber, and G. Wörheide, "A threat to coral reefs multiplied? Four species of crownof-thorns starfish," Biology Letters, vol. 4, no. 6, pp. 696-699, 2008.

[33] E. D. Crandall, M. A. Frey, R. K. Grosberg, and P. H. Barber, "Contrasting demographic history and phylogeographical patterns in two Indo-Pacific gastropods," Molecular Ecology, vol. 17, no. 2, pp. 611-626, 2008.

[34] T. S. DeBoer, M. D. Subia, Ambariyanto, M. V. Erdmann, K. Kovitvongsa, and P. H. Barber, "Phylogeography and limited genetic connectivity in the endangered boring giant clam across the coral triangle," Conservation Biology, vol. 22, no. 5, pp. 1255-1266, 2008.

[35] M. Kochzius and A. Nuryanto, "Strong genetic population structure in the boring giant clam, Tridacna crocea, across the Indo-Malay Archipelago: implications related to evolutionary processes and connectivity," Molecular Ecology, vol. 17, no. 17, pp. 3775-3787, 2008.

[36] R. G. Ravago-Gotanco, R. M. Magsino, and M. A. JuinioMeñez, "Influence of the North Equatorial Current on the population genetic structure of Tridacna crocea (Mollusca: Tridacnidae) along the eastern Philippine seaboard," Marine Ecology Progress Series, vol. 336, pp. 161-168, 2007.

[37] A. Nuryanto and M. Kochzius, "Highly restricted gene flow and deep evolutionary lineages in the giant clam Tridacna maxima," Coral Reefs, vol. 28, no. 3, pp. 607-619, 2009.

[38] D. G. Reid, K. Lal, J. MacKenzie-Dodds, F. Kaligis, D. T. J. Littlewood, and S. T. Williams, "Comparative phylogeography and species boundaries in Echinolittorina snails in the central Indo-West Pacific," Journal of Biogeography, vol. 33, no. 6, pp. 990-1006, 2006.

[39] A. Schiller, P. R. Oke, G. Brassington et al., "Eddy-resolving ocean circulation in the Asian-Australian region inferred from an ocean reanalysis effort," Progress in Oceanography, vol. 76, no. 3, pp. 334-365, 2008.

[40] H. S. Ladd, "Origin of the Pacific island molluscan fauna," American Journal of Science, vol. 258-A, pp. 137-150, 1960.
[41] P. Jokiel and F. J. Martinelli, "The vortex model of coral reef biogeography," Journal of Biogeography, vol. 19, no. 4, pp. 449-458, 1992.

[42] J. C. Briggs, "Coincident biogeographic patterns: Indo-West Pacific Ocean,” Evolution, vol. 53, no. 2, pp. 326-335, 1999.

[43] J. C. Briggs, "Modes of speciation: Marine Indo-West Pacific," Bulletin of Marine Science, vol. 65, no. 3, pp. 645-656, 1999.

[44] W. O. McMillan and S. R. Palumbi, "Concordant evolutionary patterns among Indo-West Pacific Butterflyfishes," Proceedings of the Royal Society B, vol. 260, no. 1358, pp. 229236, 1995.

[45] M. A. Juinio-Meñez, J. Macaranas, and E. D. Gomez, "Sympatric occurrence of two subspecies of Panulirus longipes Milne Edwards, 1868 (Decapoda: Palinuridae) and biochemical evidence of interbreeding," Memoirs of the Queensland Museum, vol. 31, p. 209, 1991.

[46] R. G. Ravago and M. A. Juinio-Meñez, "Phylogenetic position of the striped-legged forms of Panulirus longipes (A. Milne-Edwards, 1868) (Decapoda, Palinuridae) inferred from mitochondrial DNA sequences," Crustaceana, vol. 75, no. 9, pp. 1047-1059, 2002.

[47] L. A. Rocha, M. T. Craig, and B. W. Bowen, "Phylogeography and the conservation of coral reef fishes," Coral Reefs, vol. 26, no. 3, pp. 501-512, 2007.

[48] S. A. Lourie and A. C. J. Vincent, "A marine fish follows Wallace's Line: the phylogeography of the three-spot seahorse (Hippocampus trimaculatus, Syngnathidae, Teleostei) in Southeast Asia," Journal of Biogeography, vol. 31, no. 12, pp. 1975-1985, 2004.

[49] T. Hanebuth, K. Stattegger, and P. M. Grootes, "Rapid flooding of the Sunda Shelf: a late-glacial sea-level record," Science, vol. 288, no. 5468, pp. 1033-1035, 2000.

[50] S. R. Palumbi, "Molecular biogeography of the Pacific," Coral Reefs, vol. 16, no. 1, pp. S47-S52, 1997.

[51] P. H. Barber, "The challenge of understanding the Coral Triangle biodiversity hotspot," Journal of Biogeography, vol. 36, no. 10, pp. 1845-1846, 2009.

[52] D. Halas and R. Winterbottom, "A phylogenetic test of multiple proposals for the origins of the East Indies coral reef biota," Journal of Biogeography, vol. 36, no. 10, pp. 18471860, 2009.

[53] M. C. M. D. Malay and G. Paulay, "Peripatric speciation drives diversification and distributional pattern of reef hermit crabs (Decapoda: Diogenidae: Calcinus)," Evolution, vol. 64, no. 3, pp. 634-662, 2010.

[54] J. A. H. Benzie, E. Ballment, A. T. Forbes et al., "Mitochondrial DNA variation in Indo-Pacific populations of the giant tiger prawn, Penaeus monodon," Molecular Ecology, vol. 11, no. 12, pp. 2553-2569, 2002.

[55] J. Timm, M. Figiel, and M. Kochzius, "Contrasting patterns in species boundaries and evolution of anemonefishes (Amphiprioninae, Pomacentridae) in the centre of marine biodiversity," Molecular Phylogenetics and Evolution, vol. 49, no. 1, pp. 268-276, 2008.

[56] G. J. Vermeij, "The dispersal barrier in the tropical Pacific: implications for molluscan speciation and extinction," Evolution, vol. 41, no. 5, pp. 1046-1058, 1987.

[57] G. Paulay, "Effects of late Cenozoic sea-level fluctuations on the bivalve faunas of tropical oceanic islands," Paleobiology, vol. 16, no. 4, pp. 415-434, 1990.

[58] G. Paulay, "Biodiversity on oceanic islands: its origin and extinction," American Zoologist, vol. 34, no. 1, pp. 134-144, 1994. 
[59] C. Fauvelot, G. Bernardi, and S. Planes, "Reductions in the mitochondrial DNA diversity of coral reef fish provide evidence of population bottlenecks resulting from holocene sea-level change," Evolution, vol. 57, no. 7, pp. 1571-1583, 2003.

[60] E. D. Crandall, J. R. Taffel, and P. H. Barber, "High gene flow due to pelagic larval dispersal among South Pacific archipelagos in two amphidromous gastropods (Neritomorpha: Neritidae)," Heredity, 2009.

[61] L. A. Rocha, C. R. Rocha, D. R. Robertson, and B. W. Bowen, "Comparative phylogeography of Atlantic reef fishes indicates both origin and accumulation of diversity in the Caribbean," BMC Evolutionary Biology, vol. 8, no. 1, article 157, 2008.

[62] J. C. Briggs, "Diversity, endemism and evolution in the Coral Triangle," Journal of Biogeography, vol. 36, no. 10, pp. 20082010, 2009.

[63] G. Paulay and C. Meyer, "Diversification in the tropical Pacific: comparisons between marine and terrestrial systems and the importance of founder speciation," Integrative and Comparative Biology, vol. 42, no. 5, pp. 922-934, 2002.

[64] G. Paulay and C. Meyer, "Dispersal and divergence across the greatest ocean region: do larvae matter?" Integrative and Comparative Biology, vol. 46, no. 3, pp. 269-281, 2006.

[65] M. J. Hickerson and C. P. Meyer, "Testing comparative phylogeographic models of marine vicariance and dispersal using a hierarchical Bayesian approach," BMC Evolutionary Biology, vol. 8, no. 1, article 322, 2008.

[66] J. C. Avise, Phylogeography-The History and Formation of Species, Harvard University Press, Cambridge, Mass, USA, 2000.

[67] M. J. Hickerson, B. C. Carstens, J. Cavender-Bares et al., "Phylogeography's past, present, and future: 10 years after Avise, 2000," Molecular Phylogenetics and Evolution, vol. 54, no. 1, pp. 291-301, 2010.

[68] C. Moritz, 'Defining 'evolutionarily significant units' for conservation," Trends in Ecology and Evolution, vol. 9, no. 10, pp. 373-375, 1994.

[69] J.-P. Féral, "How useful are the genetic markers in attempts to understand and manage marine biodiversity?" Journal of Experimental Marine Biology and Ecology, vol. 268, no. 2, pp. 121-145, 2002.

[70] S. R. Palumbi, "Population genetics, demographic connectivity, and the design of marine reserves," Ecological Applications, vol. 13, no. 1, pp. S146-S158, 2003.

[71] R. S. Waples, A. E. Punt, and J. M. Cope, "Integrating genetic data into management of marine resources: how can we do it better?" Fish and Fisheries, vol. 9, no. 4, pp. 423-449, 2008.

[72] K. A. Selkoe, C. M. Henzler, and S. D. Gaines, "Seascape genetics and the spatial ecology of marine populations," Fish and Fisheries, vol. 9, no. 4, pp. 363-377, 2008.

[73] D. Hedgecock, P. H. Barber, and S. Edmands, "Genetic approaches to measuring connectivity," Oceanography, vol. 20, pp. 70-79, 2007.

[74] M. E. Hellberg, "Gene flow and isolation among populations of marine animals," Annual Review of Ecology, Evolution, and Systematics, vol. 40, pp. 291-310, 2009.

[75] W. H. Lowe and F. W. Allendorf, "What can genetics tell us about population connectivity?" Molecular Ecology, vol. 19, no. 15, pp. 3038-3051, 2010.

[76] S. Lavery, C. Moritz, and D. R. Fielder, "Indo-Pacific population structure and evolutionary history of the coconut crab Birgus latro," Molecular Ecology, vol. 5, no. 4, pp. 557570, 1996.
[77] S. T. Williams and J. A. H. Benzie, "Indo-West pacific patterns of genetic differentiation in the high-dispersal starfish Linckia laevigata," Molecular Ecology, vol. 6, no. 6, pp. 559-573, 1997.

[78] S. T. Williams and J. A. H. Benzie, "Evidence of a biogeographic break between populations of a high dispersal starfish: congruent regions within the Indo-West Pacific defined by color morphs, mtDNA, and allozyme data," Evolution, vol. 52, no. 1, pp. 87-99, 1998.

[79] T. F. Duda Jr. and S. R. Palumbi, "Population structure of the black tiger prawn, Penaeus monodon, among western Indian Ocean and western Pacific populations," Marine Biology, vol. 134, no. 4, pp. 705-710, 1999.

[80] J. A. H. Benzie, "Major genetic differences between crown-ofthorns starfish (Acanthaster planci) populations in the Indian and Pacific oceans," Evolution, vol. 53, no. 6, pp. 1782-1795, 1999.

[81] G. Wörheide, L. S. Epp, and L. Macis, "Deep genetic divergences among Indo-Pacific populations of the coral reef sponge Leucetta chagosensis (Leucettidae): founder effects, vicariance, or both?" BMC Evolutionary Biology, vol. 8, no. 1 , article 24, 2008.

[82] M. A. Ablan, J. W. McManus, C. A. Chen et al., "Population inter-dependencies in the South China Sea Ecosystem," Tech. Rep., ICLARM -The World Fish Center, Penang, Malaysia, 1999, (submitted to the John D. Catherine T. MacArthur Foundation).

[83] C. A. Chen, M. C. A. Ablan, J. W. McManus et al., "Population structure and genetic variability of six bar wrasse (Thallasoma hardwicki) in northern South China Sea revealed by mitochondrial control region sequences," Marine Biotechnology, vol. 6, no. 4, pp. 312-326, 2004.

[84] M. Leray, R. Beldade, S. J. Holbrook, R. J. Schmitt, S. Planes, and G. Bernardi, "Allopatric divergence and speciation in coral reef fish: the three-spot dascyllus, Dascyllus trimaculatus, species complex," Evolution, vol. 64, no. 5, pp. 1218-1230, 2010.

[85] S. A. Lourie, D. M. Green, and A. C. J. Vincent, "Dispersal, habitat differences, and comparative phylogeography of Southeast Asian seahorses (Syngnathidae: Hippocampus)," Molecular Ecology, vol. 14, no. 4, pp. 1073-1094, 2005.

[86] R. M. Magsino and M. A. Juinio-Meñez, "The influence of contrasting life history traits and oceanic processes on genetic structuring of rabbitfish populations Siganus argenteus and Siganus fuscescens along the eastern Philippine coasts," Marine Biology, vol. 154, no. 3, pp. 519-532, 2008.

[87] J. Drew and P. H. Barber, "Sequential cladogenesis of the reef fish Pomacentrus moluccensis (Pomacentridae) supports the peripheral origin of marine biodiversity in the IndoAustralian archipelago," Molecular Phylogenetics and Evolution, vol. 53, no. 1, pp. 335-339, 2009.

[88] M. Kochzius, C. Seidel, J. Hauschild et al., "Genetic population structures of the blue starfish Linckia laevigata and its gastropod ectoparasite Thyca crystallina," Marine Ecology Progress Series, vol. 396, pp. 211-219, 2009.

[89] S. T. Williams, "Species boundaries in the starfish genus Linckia," Marine Biology, vol. 136, no. 1, pp. 137-148, 2000.

[90] R. M. Magsino, R. G. Ravago, and M. A. Juinio-Meñez, "Genetic relationship of Linckia laevigata color morphs in the Kalayaan Islands Group, western Philippines: preliminary evidence," in Proceedings of the 9th International Coral Reef Symposium, vol. 1, pp. 113-120, Bali, Indonesia, 2002.

[91] P. H. Barber, S. R. Palumbi, M. V. Erdmann, and M. K. Moosa, "Biogeography: a marine Wallace's line?" Nature, vol. 406, no. 6797, pp. 692-693, 2000. 
[92] P. H. Barber, S. R. Palumbi, M. V. Erdmann, and M. K. Moosa, "Sharp genetic breaks among populations of Haptosquilla pulchella (Stomatopoda) indicate limits to larval transport: patterns, causes, and consequences," Molecular Ecology, vol. 11, no. 4, pp. 659-674, 2002.

[93] L. A. Kirkendale and C. P. Meyer, "Phylogeography of the Patelloida profunda group (Gastropoda: Lottidae): diversification in a dispersal-driven marine system," Molecular Ecology, vol. 13, no. 9, pp. 2749-2762, 2004.

[94] Imron, B. Jeffrey, P. Hale, B. M. Degnan, and S. M. Degnan, "Pleistocene isolation and recent gene flow in Haliotis asinina, an Indo-Pacific vetigastropod with limited dispersal capacity," Molecular Ecology, vol. 16, no. 2, pp. 289-304, 2007.

[95] L. M. Tsang, B. K. K. Chan, T. H. Wu et al., "Population differentiation in the barnacle Chthamalus malayensis: postglacial colonization and recent connectivity across the Pacific and Indian Oceans," Marine Ecology Progress Series, vol. 364, pp. 107-118, 2008.

[96] L. Knittweis, W. E. Kraemer, J. Timm, and M. Kochzius, "Genetic structure of Heliofungia actiniformis (Scleractinia: Fungiidae) populations in the Indo-Malay Archipelago: implications for live coral trade management efforts," Conservation Genetics, vol. 10, no. 1, pp. 241-249, 2009.

[97] C. J. Starger, P. H. Barber, Ambariyanto, and A. C. Baker, "The recovery of coral genetic diversity in the Sunda Strait following the 1883 eruption of Krakatau," Coral Reefs, vol. 29, no. 3, pp. 547-565, 2010.

[98] C. Perrin and P. Borsa, "Mitochondrial DNA analysis of the geographic structure of Indian scad mackerel in the IndoMalay archipelago," Journal of Fish Biology, vol. 59, no. 5, pp. 1421-1426, 2001.

[99] M. A. Ablan, "Genetics and the study of fisheries connectivity in Asian developing countries," Fisheries Research, vol. 78, no. 2-3, pp. 158-168, 2006.

[100] R. G. Ravago-Gotanco and M. A. Juinio-Meñez, "Phylogeography of the mottled spinefoot Siganus fuscescens: pleistocene divergence and limited genetic connectivity across the Philippine archipelago," Molecular Ecology. In press.

[101] S. Planes and C. Fauvelot, "Isolation by distance and vicariance drive genetic structure of a coral reef fish in the Pacific Ocean," Evolution, vol. 56, no. 2, pp. 378-399, 2002.

[102] R. G. Ravago-Gotanco and M. A. Juinio-Meñez, "Population genetic structure of the milkfish, Chanos chanos, based on PCR-RFLP analysis of the mitochondrial control region," Marine Biology, vol. 145, no. 4, pp. 789-801, 2004.

[103] L. K. Bay, J. H. Choat, L. van Herwerden, and D. R. Robertson, "High genetic diversities and complex genetic structure in an Indo-Pacific tropical reef fish (Chlorurus sordidus): evidence of an unstable evolutionary past?" Marine Biology, vol. 144, no. 4, pp. 757-767, 2004.

[104] M. R. Gaither, R. J. Toonen, D. R. Robertson, S. Planes, and B. W. Bowen, "Genetic evaluation of marine biogeographical barriers: perspectives from two widespread Indo-Pacific snappers (Lutjanus kasmira and Lutjanus fulvus)," Journal of Biogeography, vol. 37, no. 1, pp. 133-147, 2010.

[105] G. Bernardi and A. Vagelli, "Population structure in Banggai cardinalfish, Pterapogon kauderni, a coral reef species lacking a pelagic larval phase," Marine Biology, vol. 145, no. 4, pp. 803-810, 2004.

[106] E. A. Hoffman, N. Kolm, A. Berglund, J. R. Arguello, and A. G. Jones, "Genetic structure in the coral-reef-associated Banggai cardinalfish, Pterapogon kauderni," Molecular Ecology, vol. 14, no. 5, pp. 1367-1375, 2005.
[107] A. Vagelli, M. Burford, and G. Bernardi, "Fine scale dispersal in Banggai Cardinalfish, Pterapogon kauderni, a coral reef species lacking a pelagic larval phase," Marine Genomics, vol. 1, no. 3-4, pp. 129-134, 2008.

[108] J. S. Nelson, R. J. Hoddell, L. M. Chou, W. K. Chan, and V. P. E. Phang, "Phylogeographic structure of false clownfish, Amphiprion ocellaris, explained by sea level changes on the Sunda shelf," Marine Biology, vol. 137, no. 4, pp. 727-736, 2000.

[109] J. R. Ovenden, J. Salini, S. O’Connor, and R. Street, "Pronounced genetic population structure in a potentially vagile fish species (Pristipomoides multidens, Teleostei; Perciformes; Lutjanidae) from the East Indies triangle," Molecular Ecology, vol. 13, no. 7, pp. 1991-1999, 2004.

[110] A. Rohfritsch and P. Borsa, "Genetic structure of Indian scad mackerel Decapterus russelli: Pleistocene vicariance and secondary contact in the Central Indo-West Pacific Seas," Heredity, vol. 95, no. 4, pp. 315-326, 2005.

[111] Z. H. Sulaiman and J. R. Ovenden, "Population genetic evidence for the east-west division of the narrow-barred Spanish mackerel (Scomberomorus commerson, Perciformes: Teleostei) along Wallace's Line," Biodiversity and Conservation, vol. 19, pp. 563-574, 2009.

[112] H. A. Lessios, B. D. Kessing, D. R. Robertson, and G. Paulay, "Phylogeography of the pantropical sea urchin Eucidaris in relation to land barriers and ocean currents," Evolution, vol. 53, no. 3, pp. 806-817, 1999.

[113] H. A. Lessios, B. D. Kessing, and J. S. Pearse, "Population structure and speciation in tropical seas: global phylogeography of the sea urchin Diadema," Evolution, vol. 55, no. 5, pp. 955-975, 2001.

[114] H. A. Lessios, J. Kane, and D. R. Robertson, "Phylogeography of the pantropical sea urchin Tripneustes: contrasting patterns of population structure between oceans," Evolution, vol. 57, no. 9, pp. 2026-2036, 2003.

[115] S. Arnaud, F. Bonhomme, and P. Borsa, "Mitochondrial DNA analysis of the genetic relationships among populations of scad mackerel (Decapterus macarellus, D. macrosoma, and D. russelli) in South-East Asia," Marine Biology, vol. 135, no. 4, pp. 699-707, 1999.

[116] B. W. Bowen, A. L. Bass, L. A. Rocha, W. S. Grant, and D. R. Robertson, "Phylogeography of the trumpetfishes (Aulostomus): ring species complex on a global scale," Evolution, vol. 55, no. 5, pp. 1029-1039, 2001.

[117] O. S. Klanten, J. H. Choat, and L. van Herwerden, "Extreme genetic diversity and temporal rather than spatial partitioning in a widely distributed coral reef fish," Marine Biology, vol. 150, no. 4, pp. 659-670, 2007.

[118] J. B. Horne, L. van Herwerden, J. H. Choat, and D. R. Robertson, "High population connectivity across the IndoPacific: congruent lack of phylogeographic structure in three reef fish congeners," Molecular Phylogenetics and Evolution, vol. 49, no. 2, pp. 629-638, 2008.

[119] M. D. Santos, G. V. Lopez, and N. C. Barut, "A pilot study on the genetic variation of eastern little tuna (Euthynnus affinis) in Southeast Asia," Philippine Journal of Science, vol. 139, no. 1, pp. 43-50, 2010.

[120] M. T. Craig, J. A. Eble, B. W. Bowen, and D. R. Robertson, "High genetic connectivity across the Indian and Pacific Oceans in the reef fish Myripristis berndti (Holocentridae)," Marine Ecology Progress Series, vol. 334, pp. 245-254, 2007.

[121] W. S. Grant and B. W. Bowen, "Shallow population histories in deep evolutionary lineages of marine fishes: insights from 
sardines and anchovies and lessons for conservation," Journal of Heredity, vol. 89, no. 5, pp. 415-426, 1998.

[122] J. -O. Irisson, C. Guigand, and C. B. Paris, "Detection and quantification of marine larvae orientation in the pelagic environment," Limnology and Oceanography: Methods, vol. 7, pp. 664-672, 2009.

[123] G. P. Jones, S. Planes, and S. R. Thorrold, "Coral reef fish larvae settle close to home," Current Biology, vol. 15, no. 14, pp. 1314-1318, 2005.

[124] G. Gerlach, J. Atema, M. J. Kingsford, K. P. Black, and V. Miller-Sims, "Smelling home can prevent dispersal of reef fish larvae," Proceedings of the National Academy of Sciences of the United States of America, vol. 104, no. 3, pp. 858-863, 2007.

[125] M. Bailey and T. J. Pitcher, Eds., "Ecological and economic analyses of the bird's head seascape, Papua, Indonesia: II," Fisheries Centre Research Reports, vol. 16, no. 1, p. 1186, 2008.

[126] Y. Y. Kim, T. Qu, T. Jensen et al., "Seasonal and interannual variations of the North Equatorial current bifurcation in a high-resolution OGCM," Journal of Geophysical Research C, vol. 109, no. 3, Article ID C03040, 19 pages, 2004.

[127] Q. Y. Wang, R. X. Cao, S. W. Zhang, and D. X. Hu, "Bifurcation of pacific north equatorial current at the surface," Science in China, Series D, vol. 52, no. 2, pp. 227-231, 2009.

[128] M. D. Spalding, H. E. Fox, G. R. Allen et al., "Marine ecoregions of the world: a bioregionalization of coastal and shelf areas," BioScience, vol. 57, no. 7, pp. 573-583, 2007.

[129] P. M. Aliño and E. D. Gomez, "Philippine coral reef conservation: its significance to the South China Sea," in Development and Conservation in the Asia-Pacific Region, Proceedings of the Regional Conference of the East-West Center Association, K. Yamamoto, S. Ishijima, S. Sakihara et al., Eds., pp. 222-229, 1994.

[130] C. L. Remington, "Suture-zones of hybrid interaction between recently joined biotas," Evolutionary Biology, vol. 2, pp. 321-428, 1968.

[131] G. Hewitt, "The genetic legacy of the quaternary ice ages," Nature, vol. 405, no. 6789, pp. 907-913, 2000.

[132] J. A. H. Benzie, "Genetic structure of coral reef organisms: ghosts of dispersal past," American Zoologist, vol. 39, no. 1, pp. 131-145, 1999.

[133] J.-P. A. Hobbs, A. J. Frisch, G. R. Allen, and L. van Herwerden, "Marine hybrid hotspot at Indo-Pacific biogeographic border," Biology Letters, vol. 5, no. 2, pp. 258-261, 2009.

[134] A. D. Marie, L. van Herwerden, J. H. Choat, and J.-P. A. Hobbs, "Hybridization of reef fishes at the Indo-Pacific biogeographic barrier: a case study," Coral Reefs, vol. 26, no. 4, pp. 841-850, 2007.

[135] S. T. Williams, J. Jara, E. Gomez, and N. Knowlton, "The Marine Indo-West Pacific break: contrasting the resolving power of mitochondrial and nuclear genes," Integrative and Comparative Biology, vol. 42, no. 5, pp. 941-952, 2002.

[136] N. H. Barton and G. M. Hewitt, "Analysis of hybrid zones," Annual Review of Ecology and Systematics, vol. 16, pp. 113148, 1985.

[137] L. Excoffier, M. Foll, and R. J. Petit, "Genetic consequences of range expansions," Annual Review of Ecology, Evolution, and Systematics, vol. 40, pp. 481-501, 2009.

[138] D. Tager, J. M. Webster, D. C. Potts, W. Renema, J. C. Braga, and J. M. Pandolfi, "Community dynamics of Pleistocene coral reefs during alternative climatic regimes," Ecology, vol. 91, no. 1, pp. 191-200, 2010.
[139] D. Tautz, H. Ellegren, and D. Weigel, "Next generation molecular ecology," Molecular Ecology, vol. 19, supplement 1, pp. 1-3, 2010.

[140] C. L. Richards, B. C. Carstens, and L. L. Knowles, "Distribution modelling and statistical phylogeography: an integrative framework for generating and testing alternative biogeographical hypotheses," Journal of Biogeography, vol. 34, no. 11, pp. 1833-1845, 2007.

[141] E. A. Treml, P. N. Halpin, D. L. Urban, and L. F. Pratson, "Modeling population connectivity by ocean currents, a graph-theoretic approach for marine conservation," Landscape Ecology, vol. 23, no. 1, pp. 19-36, 2008.

[142] P. Saenz-Agudelo, G. P. Jones, S. R. Thorrold, and S. Planes, "Estimating connectivity in marine populations: an empirical evaluation of assignment tests and parentage analysis under different gene flow scenarios," Molecular Ecology, vol. 18, no. 8, pp. 1765-1776, 2009.

[143] S. Planes, G. P. Jones, and S. R. Thorrold, "Larval dispersal connects fish populations in a network of marine protected areas," Proceedings of the National Academy of Sciences of the United States of America, vol. 106, no. 14, pp. 5693-5697, 2009. 

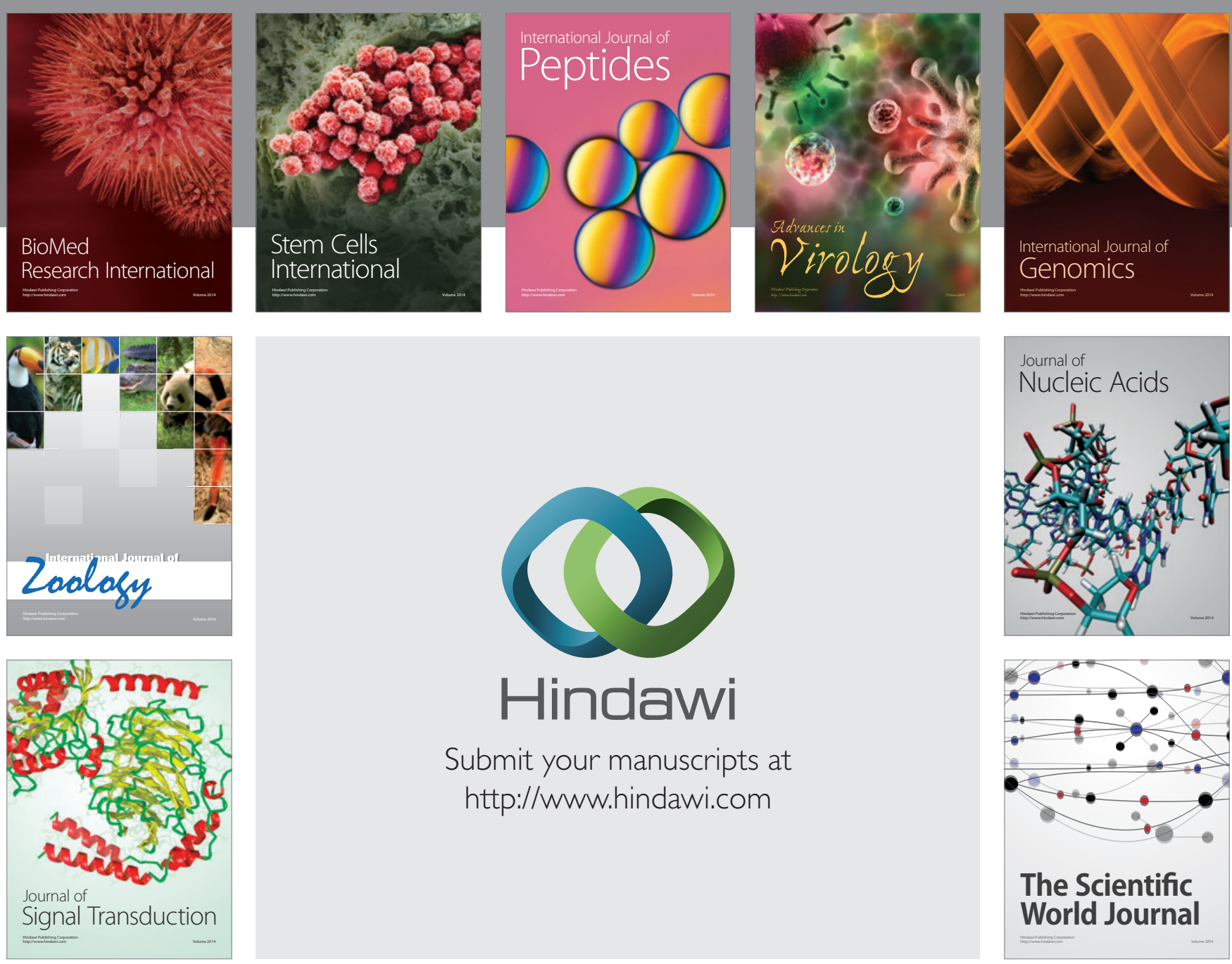

Submit your manuscripts at

http://www.hindawi.com
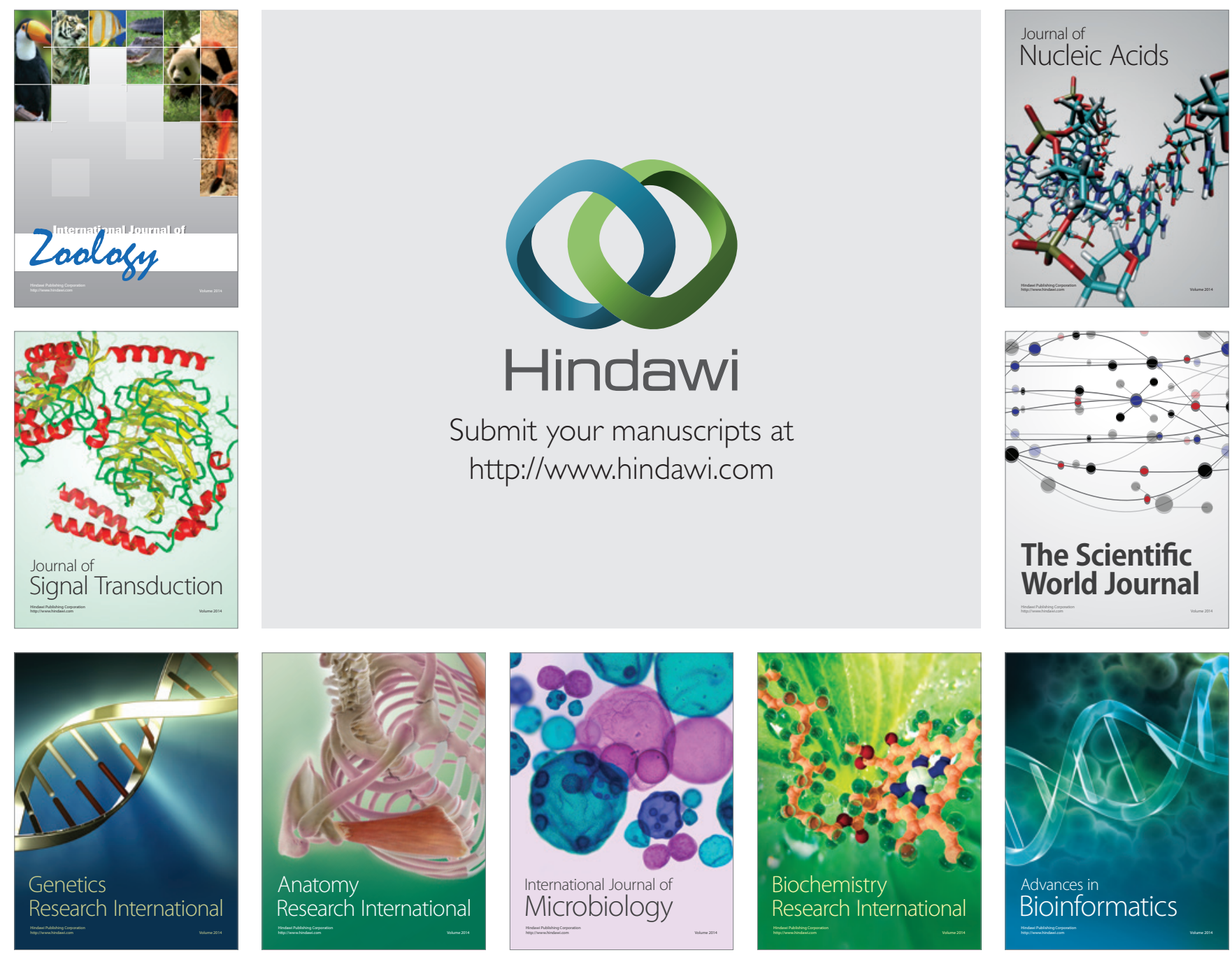

The Scientific World Journal
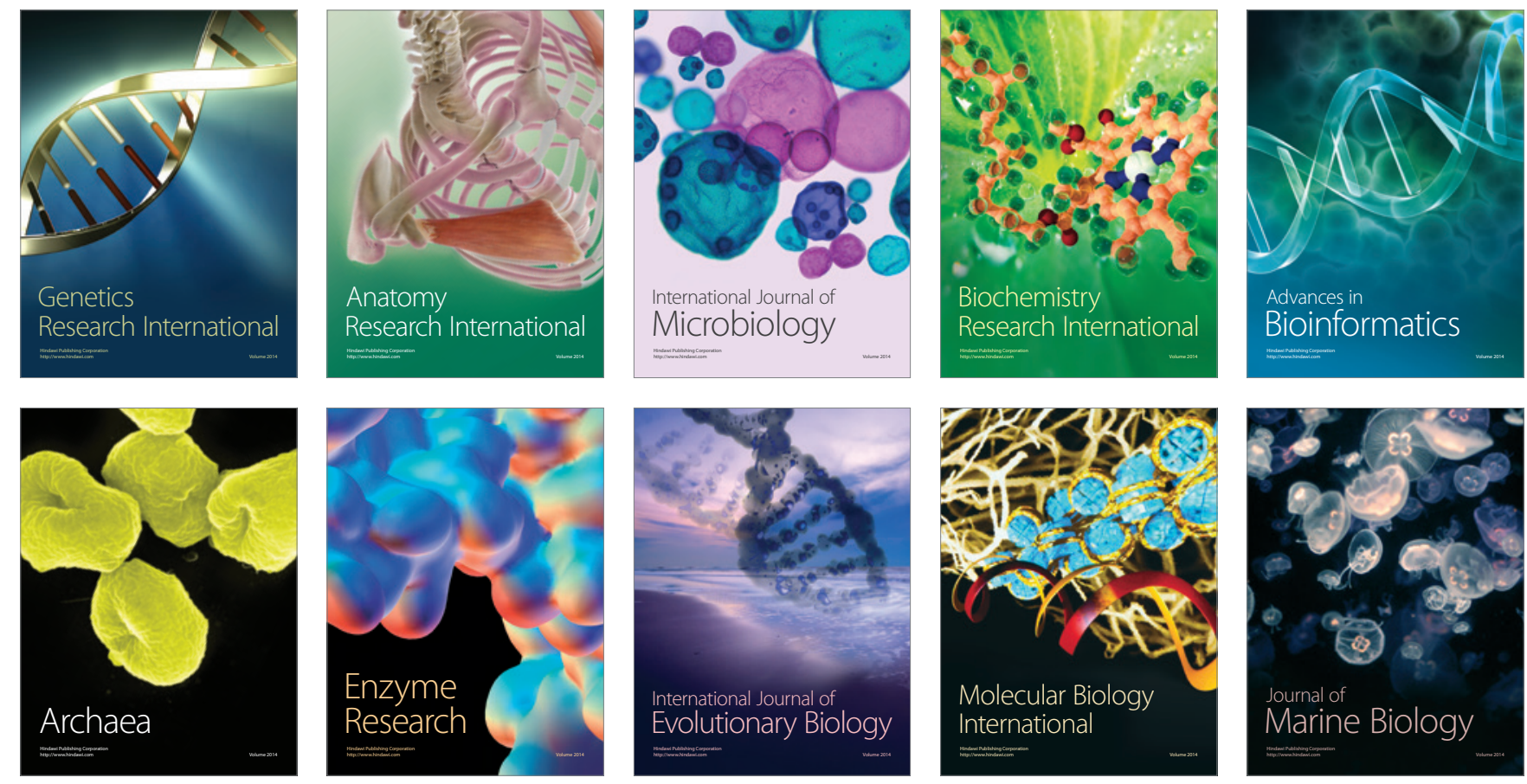